\title{
Lung Hypoplasia Can Be Reversed by Short-Term Obstruction of the Trachea in Fetal Sheep
}

LAURA NARDO, STUART B. HOOPER, AND RICHARD HARDING

Fetal and Neonatal Research Unit, Department of Physiology, Monash University, Clayton, Victoria, Australia 3168

\section{ARSTRACT}

Our aim was to determine whether an existing lung growth deficit could be reversed, in utero, by short-term (6d) obstruction of the fetal trachea. Chronically catheterized fetal sheep (term $\sim 145 \mathrm{~d}$ ) were divided into four groups: 1) no treatment (control); 2) continuous lung liquid drainage to induce lung hypoplasia (105-134 d, drain); 3) lung liquid drainage to induce lung hypoplasia (105-128 d), followed by restoration of tracheal flow (128-134 d, drain and reconnect); and 4) lung liquid drainage to induce lung hypoplasia (105-128 d), followed by tracheal occlusion to accelerate lung growth (128-134 d, drain and obstruct). Lung liquid volumes and secretion rates were measured on $\mathrm{d} 125$, 130 , and 134 of gestation and postmortem data collected on d 135. Compared with controls, continuous lung liquid drainage (drain) significantly reduced wet lung weights $(34.3 \pm 2.6 \mathrm{~g} / \mathrm{kg}$ versus $13.3 \pm 1.4 \mathrm{~g} / \mathrm{kg})$ and total lung DNA contents $(177 \pm 11$ $\mathrm{mg} / \mathrm{kg}$ versus $94 \pm 7 \mathrm{mg} / \mathrm{kg}$ ). Reestablishing tracheal flow for $6 \mathrm{~d}$ (drain and reconnect) increased fetal lung wet weights (19.2 \pm $1.6 \mathrm{~g} / \mathrm{kg}$ ), but not total DNA contents (106 $\pm 9 \mathrm{mg} / \mathrm{kg})$, compared with lung liquid drained fetuses (drain). After $6 \mathrm{~d}$ of tracheal obstruction (drain and obstruct) lung liquid volumes, wet lung weights, and total protein contents (weight, $28.6 \pm 2.8 \mathrm{~g} / \mathrm{kg}$; protein, $1376 \pm 97 \mathrm{mg} / \mathrm{kg}$ ) were similar to control values (weight, $34.3 \pm 2.6 \mathrm{~g} / \mathrm{kg}$; protein, $1506 \pm 123 \mathrm{mg} / \mathrm{kg}$ ); lung DNA contents were less than control but greater than values from lung liquid drained fetuses (drain and obstruct, $140 \pm 9 \mathrm{mg} / \mathrm{kg}$ versus drain, $94 \pm 7 \mathrm{mg} / \mathrm{kg}$ ). We conclude that obstruction of the trachea can reverse an existing fetal lung growth deficit in approximately $6 \mathrm{~d}$, whereas merely restoring tracheal continuity does not increase fetal lung growth. (Pediatr Res 38: 690-696, 1995)
Throughout most of gestation the lungs are filled with a liquid that is secreted across the pulmonary epithelium and leaves the lungs via the trachea. It is well established that the volume of liquid retained within the future airways is critical for normal lung growth and development. Obstruction of the fetal trachea, which causes secreted lung liquid to accumulate in the future airways resulting in increased expansion of the lungs (1), greatly increases lung growth $(2,3)$. Conversely, prolonged drainage of fetal lung liquid to the exterior causes lung deflation and a near cessation of lung growth $(2,3)$. We have recently shown that the increase in lung growth induced by tracheal obstruction is very rapid and occurs within $7 \mathrm{~d}$ of blocking the fetal trachea (4). Such results have led to the suggestion that short-term periods of tracheal obstruction may rapidly reverse an existing lung growth deficit in utero $(4,5)$.

Inadequate lung growth during fetal life results in pulmonary hypoplasia at birth and is a common cause of perinatal mor-

Received October 4, 1994; accepted June 22, 1995

Correspondence: L. Nardo, Department of Physiology, Monash University, Clayton, Victoria, 3168 Australia.

Supported financially by the William Buckland Foundation and the National Health and Medical Research Council of Australia. bidity and mortality in newborn infants $(6,7)$. To avoid the postnatal consequences of fetal lung hypoplasia in humans, attempts have been made to surgically treat this condition in utero, before the lungs are required for gas exchange. However, these treatments have principally focused on correcting the underlying abnormality rather than attempting to accelerate lung growth directly $(8,9)$. As increased fetal lung expansion, resulting from tracheal obstruction, is a potent and rapid way of accelerating fetal lung growth (2-4), we considered it possible that tracheal obstruction may rapidly reverse an existing lung growth deficit in utero. The aim of this study was to determine whether fetal lung hypoplasia, induced by prolonged lung liquid drainage, could be reversed by short-term obstruction of the fetal trachea. The effect of this treatment was also compared with the effect of ceasing the drainage and reestablishing tracheal flow without imposing an increase in lung distension. We considered this procedure to be analogous to the correction of an underlying abnormality (e.g. diaphragmatic hernia) that causes lung hypoplasia in human fetuses and postulated that it would not sufficiently increase intraluminal pressure to reexpand the lungs and stimulate lung growth. As any potential increase in lung growth was likely to depend upon the reex- 
pansion of the hypoplastic fetal lungs with liquid, we also monitored the changes in lung liquid secretion and volume during each of the treatments.

\section{METHODS}

Surgery was performed on 17 pregnant ewes (BorderLeicester $\times$ Merino) at $100 \mathrm{~d}$ of gestation (term is $\sim 145 \mathrm{~d}$ ). Anesthesia was induced with thiopental sodium (1 g, i.v.) and was maintained, after tracheal intubation, with $1.5 \%$ halothane in $\mathrm{O}_{2}-\mathrm{N}_{2} \mathrm{O}(50: 50 \mathrm{vol} / \mathrm{vol})$. In each fetus, two silicone rubber cannulas (Dow Corning, catalog no. 601-365) were implanted 2-4 $\mathrm{cm}$ into the trachea, one directed toward the lungs and the other directed toward, but not entering, the larynx. These catheters were joined together to form an exteriorized tracheal loop. Polyvinyl catheters were also implanted into a fetal carotid artery and jugular vein for blood sampling. Antibiotics ( $2 \mathrm{~mL}$, intramuscularly, Depomycin; Intervet, Australia) were administered to the fetus before the uterine incision was closed. Ewes and fetuses were allowed to recover for $5 \mathrm{~d}$ after surgery before experiments began. Fetal blood gases, $\mathrm{pH}$, and oxygen saturation (ABL30, Radiometer) were measured daily to assess fetal well being. These experiments were approved by Monash University's Committee on Ethics in Animal Experimentation.

Experimental protocol. Animals were divided into four experimental groups. In the 135-d control group, fetal lung liquid was allowed to flow normally through the tracheal loop from $105-135 \mathrm{~d}$ of gestation $(n=5)$; this group served as age-matched controls for the three treatment groups (drain, drain and reconnect, drain and obstruct). (i) Drain: fetal lung liquid was drained into a sterile bag by gravity for $29 \mathrm{~d}$ (105-134 d of gestation) to induce fetal lung hypoplasia $(n=$ 4). (ii) Drain and reconnect: fetal lung liquid was drained for $23 \mathrm{~d}(105-128 \mathrm{~d})$ after which the tracheal flow was restored for $6 \mathrm{~d}(128-134 \mathrm{~d}, n=4)$. (iii) Drain and obstruct: fetal lung liquid was drained for $23 \mathrm{~d}$ (105-128 d) after which the exteriorized tracheal loop was blocked for $6 \mathrm{~d}(128-134 \mathrm{~d})$ to accelerate lung growth $(n=4)$. During the period of lung liquid drainage (in drain, drain and reconnect, and drain and obstruct groups), the volume of liquid drained was measured daily, and the time of collection was noted. A fifth group of fetuses (105-d control) were killed at $105 \mathrm{~d}$ of gestation $(n=$ 4) to determine lung weights and DNA contents at the start of the study period.

Over the last 3-4 d of the experimental period, fetal tracheal pressures, from which amniotic pressure was electronically subtracted, were recorded using Statham pressure transducers (P23ID) and displayed on a polygraph (model 7D, Grass).

On d 134 of gestation, the tracheal circuit was reconnected in all groups to allow liquid to flow along the tracheal loop. At $135 \mathrm{~d}$ of gestation, lung liquid was drained off by gravity, the volume recorded, and the tracheal loop clamped immediately before the ewe and fetus were killed by an overdose of barbiturate (i.v.). The fetal lungs, heart, liver, kidneys, and costal muscles and vertebral diaphragm muscles were weighed, and portions were rapidly frozen in liquid nitrogen and stored at $-70^{\circ} \mathrm{C}$ for subsequent analysis.
Analytical methods. The secretion rate and volume of fetal lung liquid were measured using an established method of indicator dilution (Blue Dextran 2000, Pharmacia Chemical, Sweden) (10) on d 125, 130, and 134 of gestation. When these measurements coincided with a period of continuous lung liquid drainage (e.g. on $\mathrm{d} 125$ in drain, drain and reconnect, and drain and obstruct groups), $50 \mathrm{~mL}$ of sterile saline were added to the syringe, before the introduction of $2-3.5 \mathrm{~mL}(50 \mathrm{mg} / \mathrm{mL})$ of indicator, to ensure adequate mixing of the indicator with the lung liquid. This volume $(50 \mathrm{~mL})$ was chosen because it was considered to be the smallest which would allow an accurate estimate of lung liquid volume and secretion rate. Lung liquid was alternately drained and returned to the lungs for $45 \mathrm{~min}$ to thoroughly mix the indicator. Samples of lung liquid $(1-2 \mathrm{~mL})$ were collected every $15 \mathrm{~min}$ over a $1.5-\mathrm{h}$ period for determination of indicator concentration; the rate at which the indicator was progressively diluted was used to measure the secretion rate (10). If the lung liquid volume and secretion rate measurement coincided with a period of lung liquid drainage, the drainage continued between successive sampling times. However, if the measurement occurred during a period of tracheal obstruction or was performed in fetuses with an intact tracheal circuit (135-d control, drain and reconnect, and drain and obstruct groups), the liquid that was drained was returned to the lungs between successive sampling times. At the end of the measurement period, the liquid was returned to the lung lumen, and the catheter leading to the lung lumen was reconnected to either the drain bag or the upper tracheal catheter. The volume of liquid added to the lung during these indicator dilution experiments was subtracted from both the volume measurement and the volume of lung liquid collected into the external bag the following day. The concentration of indicator in each lung liquid sample was measured using a multichannel absorbance meter (Titertek Multiscan, Flow Laboratories, UK) set at a wavelength of $620 \mathrm{~nm}$, and the values were used to calculate the secretion rate and volume of fetal lung liquid (10).

The concentration of DNA in fetal tissues was determined using a previously described method (4). Protein contents were determined by homogenizing samples before measuring the protein concentration using a standard protein assay (Bio-Rad, Australia). Bovine serum albumen standards were made up in distilled water and diluted to achieve concentrations of 100,50 , $25,12.5$, and $6.25 \mu \mathrm{g} / \mathrm{mL}$. Estimates of fetal body weights at the time of the experiments were made from postmortem weights (11).

Statistical analysis. Data in the text are presented as mean \pm SEM. Differences in lung liquid secretion rates and volumes were analyzed by three-way analysis of variance with treatment, gestational age, and animals as factors. When an interaction was found between treatment and gestational age, the data were analyzed by a two-way analysis of variance with either gestational age and animals or treatment and animals as factors. Significant differences were then identified with a Student Newman-Keuls test. DNA contents and concentrations and tissue wet and dry weights were analyzed by two-way analysis of variance with treatment and animals as factors. Differences between individual values were then identified 
with a Student Newman-Keuls test. The level of significance was $p<0.05$ for all statistical analyses.

\section{RESULTS}

All fetuses were considered healthy as judged by their blood gas and acid-base status before and throughout the experiments. Fetal body weights were not different between the treatment groups at $135 \mathrm{~d}$ of gestation (135-d control, $3.53 \pm$ $0.23 \mathrm{~kg}$; drain, $4.78 \pm 0.82 \mathrm{~kg}$; drain and reconnect, $3.93 \pm$ $0.43 \mathrm{~kg}$; and drain and obstruct, $4.38 \pm 0.23 \mathrm{~kg}$ ). The mean fetal body weight at $105 \mathrm{~d}$ of gestation (105-d control) was $1.17 \pm 0.05 \mathrm{~kg}$.

Rate of lung liquid drainage. In fetuses from which lung liquid was drained (drain, drain and reconnect, and drain and obstruct groups), the mean rate of liquid drainage increased from $3.9 \pm 0.2 \mathrm{~mL} / \mathrm{h}$ at $105 \mathrm{~d}$ to $14.4 \pm 0.5 \mathrm{~mL} / \mathrm{h}$ at $134 \mathrm{~d}$ of gestation (Fig. 1). However, when adjusted for estimated fetal body weight, the rate of lung liquid drainage did not change with increasing gestational age.

Lung liquid secretion rates. Expressed in relation to fetal body weight, the secretion rate of lung liquid was similar in control fetuses compared with fetuses exposed to continuous lung liquid drainage at 125 (drain, drain and reconnect, and drain and obstruct groups), 130 (drain) or 134 (drain) days of gestation (Fig. 2b). However, when the lung liquid secretion rates were expressed in relation to wet lung tissue weight at $135 \mathrm{~d}$ of gestation (Fig. 3), they were significantly higher in lung liquid drained fetuses (drain, $32 \pm 5 \mathrm{~mL} / \mathrm{h} / 100 \mathrm{~g}$ ) compared with controls (135-d control, $12 \pm 3 \mathrm{~mL} / \mathrm{h} / 100 \mathrm{~g}$ ).

Obstruction of the fetal trachea at $128 \mathrm{~d}$ of gestation caused a significant reduction in lung liquid secretion rates (Fig. 2b) compared with age-matched control fetuses at $130 \mathrm{~d}$ of gestation (135 d control, $3.7 \pm 0.3$ versus drain and obstruct, $0.0 \pm$ $0.2 \mathrm{~mL} / \mathrm{h} / \mathrm{kg})$, and this reduction persisted at $134 \mathrm{~d}(135-\mathrm{d}$

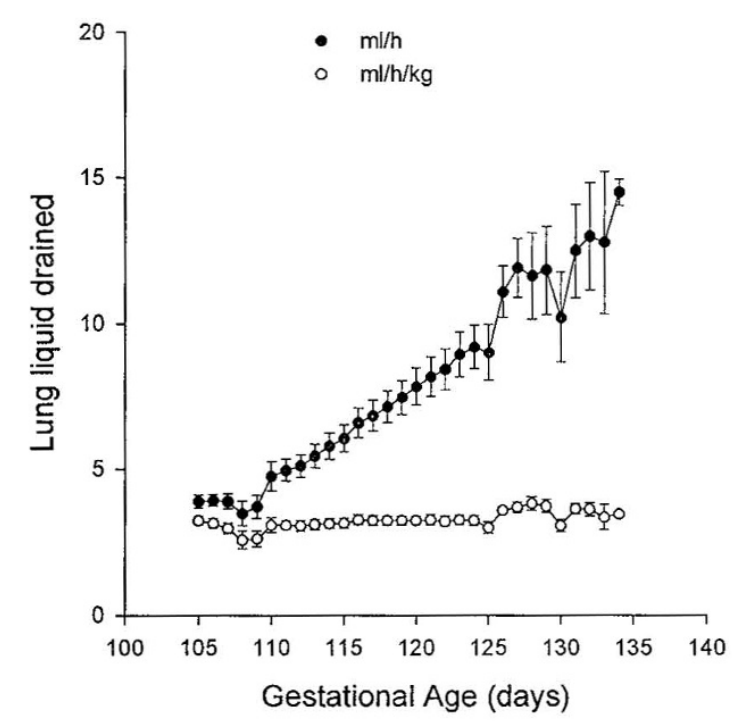

Figure 1. Absolute rate of lung liquid drained per hour (closed circles) and drainage rates adjusted for fetal body weight (open circles). Values were obtained from drain, drain and reconnect, and drain and obstruct fetuses between 105 and $128 \mathrm{~d}$ of gestation and from drain fetuses between 128 and $134 \mathrm{~d}$ of gestation.
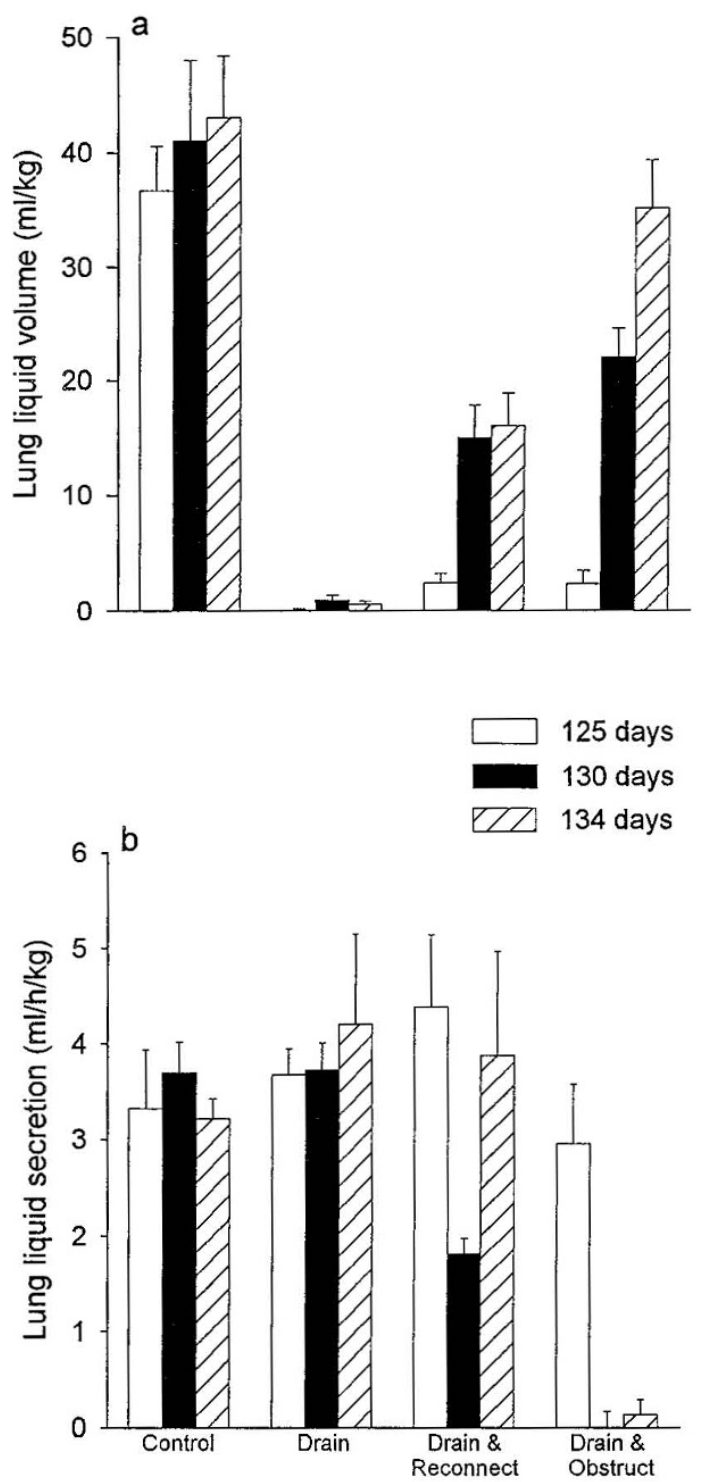

Figure 2. The volume $(a)$ and secretion rate $(b)$ of fetal lung liquid at $125 \mathrm{~d}$ (open bars), $130 \mathrm{~d}$ (solid bars), and $134 \mathrm{~d}$ (hatched bars) of gestation in control fetuses (135-d control) and fetuses that had lung liquid drained only (drain), lung liquid drained followed by reconnection of the tracheal circuit (drain and reconnect), and lung liquid drained followed by tracheal obstruction (drain and obstruct).

control, $3.2 \pm 0.2$ versus drain and obstruct, $0.1 \pm 0.2 \mathrm{~mL} / \mathrm{h} /$ $\mathrm{kg})$. Two days after reconnecting the tracheal circuit in drain and reconnect fetuses $(130 \mathrm{~d})$, lung liquid secretion rates were significantly lower than in age-matched control fetuses (135-d control, $3.7 \pm 0.3$ versus drain and reconnect, $1.8 \pm 0.2$ $\mathrm{mL} / \mathrm{h} / \mathrm{kg}$ ), but this difference did not persist at $134 \mathrm{~d}$ of gestation (135-d control, $3.2 \pm 0.2 \mathrm{~mL} / \mathrm{h} / \mathrm{kg}$ versus drain and reconnect, $3.9 \pm 1.1 \mathrm{~mL} / \mathrm{h} / \mathrm{kg}$ ) (Fig. $2 b$ ).

Fetal lung liquid volumes. The volume of lung liquid in control fetuses tended to increase with gestational age (Fig. 2a) from $36.6 \pm 3.9 \mathrm{~mL} / \mathrm{kg}$ at $125 \mathrm{~d}$ to $43.8 \pm 5.3 \mathrm{~mL} / \mathrm{kg}$ at 134 $\mathrm{d}$ of gestation. During periods of lung liquid drainage, the volume of liquid was significantly reduced to near zero at 125 d (drain, drain and reconnect, and drain and obstruct), 130 (drain) and 134 (drain) days of gestation (Fig 2a). Two days 


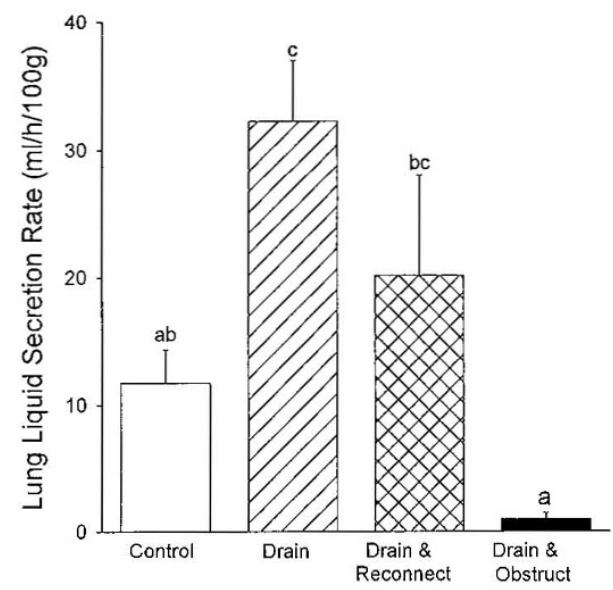

Figure 3. Rate of lung liquid secretion (mean \pm SEM), adjusted for wet lung weight, in control fetuses (open bars, 135-d control), and fetuses which were exposed to continuous lung liquid drainage (hatched bars, drain), lung liquid drainage followed by reconnection of the tracheal circuit (cross-hatched bars, drain and reconnect), and lung liquid drainage followed by tracheal obstruction (solid bars, drain and obstruct) at $134 \mathrm{~d}$ of gestation. Values which do not share a common letter are significantly different $(p<0.05)$ from each other.

after the trachea was obstructed in drain and obstruct fetuses, the volume of lung liquid was significantly greater than that measured in lung liquid drained fetuses $(130 \mathrm{~d}$, drain, $0.9 \pm 0.5$ $\mathrm{mL} / \mathrm{kg}$ versus drain and obstruct, $22.0 \pm 2.6 \mathrm{~mL} / \mathrm{kg}$ ), and after $6 \mathrm{~d}$ of tracheal obstruction (134 d) the volume was not different from control values at this age (135 d control, $43.8 \pm 5.3$ $\mathrm{mL} / \mathrm{kg}$ versus drain and obstruct, $35.1 \pm 4.2 \mathrm{~mL} / \mathrm{kg}$ ). The increase in lung liquid volume after tracheal obstruction was associated with a significant increase in tracheal pressure (drain and obstruct, $7.5 \pm 1.0 \mathrm{~mm} \mathrm{Hg}$ versus 135 -d control, $1.7 \pm 0.2$ $\mathrm{mm} \mathrm{Hg}$ ) after $6 \mathrm{~d}$. Reconnection of the tracheal circuit (drain and reconnect) also resulted in a significant increase in lung liquid volume after $2 \mathrm{~d}(130 \mathrm{~d}$, drain and reconnect, $14.9 \pm 2.8$ $\mathrm{mL} / \mathrm{kg}$ ), but the volume was not increased further at $134 \mathrm{~d}$ (16.0 $\pm 2.8 \mathrm{~mL} / \mathrm{kg}$ ) (Fig. $2 a$ ). Six days after reconnecting the tracheal circuit (134 d) lung liquid volumes were significantly lower than in control fetuses (135-d control) and fetuses with occluded tracheas (drain and obstruct) at the same age.

Fetal lung weights. Continuous drainage of lung liquid for $29 \mathrm{~d}$ (drain) caused a significant reduction in the lung (wet and dry) weight-to-body weight ratios (Table 1) compared with controls (135-d control). Although fetuses exposed to lung liquid drainage $(23 \mathrm{~d})$ followed by reconnection of the tracheal circuit (6 d) (drain and reconnect) had significantly higher wet lung-to-body weight ratios compared with lung liquid drained fetuses (drain), the dry lung-to-body weight ratios were not different. Furthermore, the wet and dry lung-to-body weight ratios in drain and reconnect fetuses were significantly lower than in control fetuses (135-d control) (Table 1). Wet lung-tobody weight ratios in fetuses exposed to lung liquid drainage $(23 \mathrm{~d})$ followed by tracheal obstruction (6 d) (drain and obstruct) were not different from control values (135-d control), although dry lung-to-body weight ratios were reduced compared with controls. In 105-d-old fetuses (105-d control), wet and dry lung weights not adjusted for body weight were similar to the lung weights of 135 -d-old fetuses after $29 \mathrm{~d}$ of continuous lung liquid drainage (drain) (Table 1).

Total lung DNA content. Total lung DNA contents relative to body weight were significantly lower in fetuses exposed to $29 \mathrm{~d}$ of lung liquid drainage than in age-matched controls (135-d control, $177 \pm 11 \mathrm{mg} / \mathrm{kg}$ versus drain, $94 \pm 7 \mathrm{mg} / \mathrm{kg}$ ) (Fig. 4a). Reconnection of the tracheal circuit for $6 \mathrm{~d}$ did not significantly increase total lung DNA contents above values in fetuses exposed to continuous lung liquid drainage (drain and reconnect: $106 \pm 9 \mathrm{mg} / \mathrm{kg}$ versus drain: $94 \pm 7 \mathrm{mg} / \mathrm{kg}$ ). However, after $6 \mathrm{~d}$ of tracheal obstruction in drain and obstruct fetuses, total lung DNA contents were significantly greater than in fetuses exposed to continuous lung liquid drainage (drain and obstruct, $140 \pm 9 \mathrm{mg} / \mathrm{kg}$ versus drain, $94 \pm 7$ $\mathrm{mg} / \mathrm{kg}$ ) and had almost reached control values (135-d control, $177 \pm 11 \mathrm{mg} / \mathrm{kg}$ ) (Fig. 4a). In 105-d-old fetuses, total lung DNA content, not adjusted for fetal body weight, was significantly greater than the DNA content of lungs from 135-d-old fetuses exposed to continuous lung liquid drainage (105-d control, $499 \pm 30 \mathrm{mg}$ versus drain, $363 \pm 37 \mathrm{mg}$ ).

Total lung protein content. The total protein content of lungs from fetuses exposed to continuous lung liquid drainage (drain) was significantly less than in age-matched controls (135-d control: $1506 \pm 123 \mathrm{mg} / \mathrm{kg}$ versus drain, $694 \pm 42$ $\mathrm{mg} / \mathrm{kg}$ ) (Fig. 4b). In drain and reconnect fetuses, $6 \mathrm{~d}$ after the tracheal circuit had been reconnected, the total lung protein content was significantly lower than control values (drain and reconnect, $722 \pm 146 \mathrm{mg} / \mathrm{kg}$ versus 135 -d control, $1506 \pm 123$ $\mathrm{mg} / \mathrm{kg}$ ) and was not different from values in lung liquid drained fetuses (drain, $694 \pm 43 \mathrm{mg} / \mathrm{kg}$ ). The total lung protein content of fetuses which had undergone lung liquid drainage followed by tracheal obstruction (drain and obstruct, $1376 \pm 97 \mathrm{mg} / \mathrm{kg}$ ) was significantly greater than fetuses exposed to lung liquid drainage alone (drain, $694 \pm 43 \mathrm{mg} / \mathrm{kg}$ ) and was not different from age-matched control fetuses (135-d control, $1506 \pm 123$ $\mathrm{mg} / \mathrm{kg}$ ) (Fig. 4b). In 105-d-old control fetuses, total lung protein content, not adjusted for fetal body weight, was similar

Table 1. Weights of lungs (wet and dry) in 105-d control fetuses, 135-d control fetuses, and fetuses exposed to continuous lung liquid drainage (drain), lung liquid drainage followed by reconnection of the tracheal circuit (drain and reconnect), and lung liquid drainage followed by tracheal obstruction (drain and obstruct)

\begin{tabular}{|c|c|c|c|c|c|}
\hline Weight & $\begin{array}{c}105-\mathrm{d} \\
\text { control }\end{array}$ & 135-d control & Drain & $\begin{array}{l}\text { Drain and } \\
\text { reconnect }\end{array}$ & $\begin{array}{c}\text { Drain and } \\
\text { obstruct }\end{array}$ \\
\hline Wet weight (g) & $58.2 \pm 4.8^{a}$ & $121.2 \pm 13.4^{b}$ & $50.6 \pm 3.6^{a}$ & $85.2 \pm 11.3^{a b}$ & $140.0 \pm 32.1^{b}$ \\
\hline Wet weight $(\mathrm{g} / \mathrm{kg})$ & $49.4 \pm 2.1^{b}$ & $34.3 \pm 2.6^{c}$ & $13.3 \pm 1.4^{a}$ & $19.2 \pm 1.6^{b}$ & $28.6 \pm 2.8^{c}$ \\
\hline Dry weight $(\mathrm{g})$ & $6.4 \pm 0.2^{a}$ & $12.3 \pm 0.9^{b}$ & $7.4 \pm 0.9^{a b}$ & $9.9 \pm 1.2^{a b}$ & $12.9 \pm 2.4^{b}$ \\
\hline Dry weight $(\mathrm{g} / \mathrm{kg})$ & $5.5 \pm 0.2^{b}$ & $3.5 \pm 0.2^{c}$ & $1.9 \pm 0.1^{a}$ & $2.2 \pm 0.2^{a b}$ & $2.7 \pm 0.1^{b}$ \\
\hline
\end{tabular}

Values which do not share a common letter are significantly different $(p<0.05)$ from each other. 

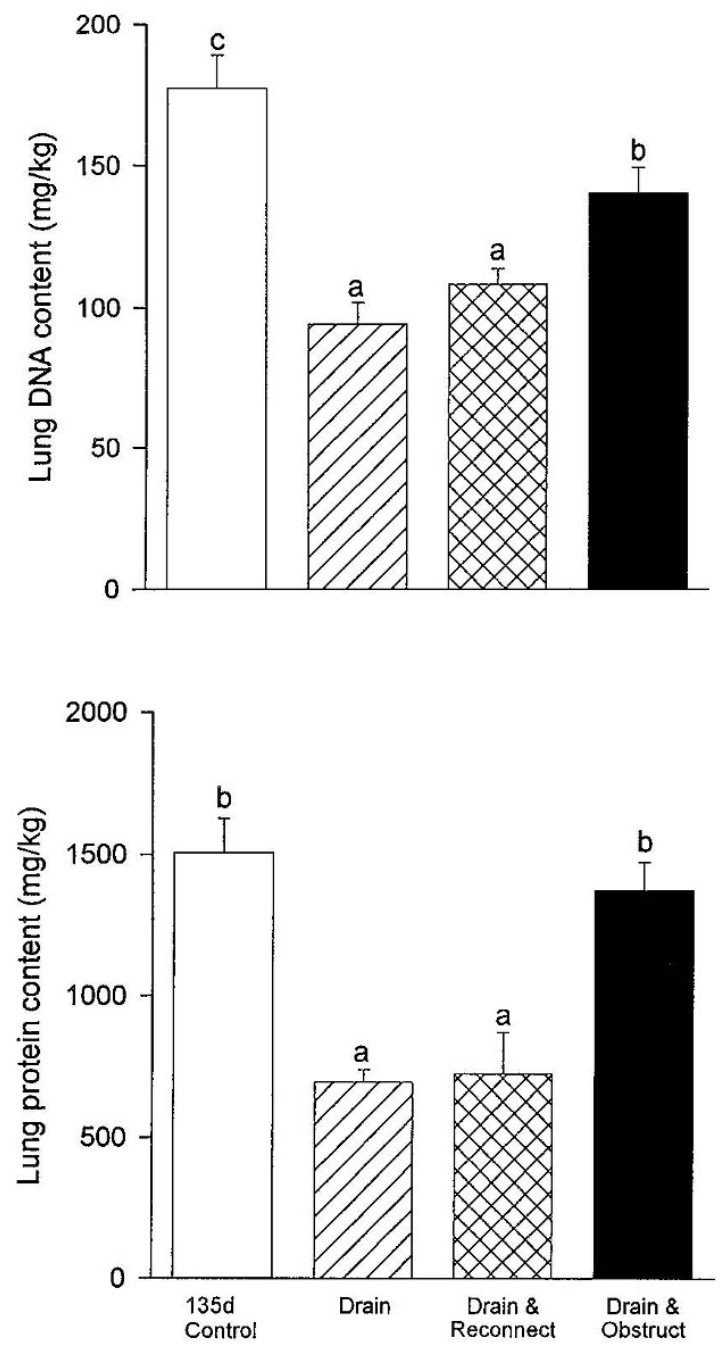

Figure 4. Total lung DNA and protein contents in 135-d control fetuses (open bars, 135-d control) and fetuses exposed to continuous lung liquid drainage (hatched bars, drain), lung liquid drainage followed by reconnection of the tracheal circuit (cross-hatched bars, drain and reconnect), and lung liquid drainage followed by tracheal obstruction (solid bars, drain and obstruct). Values with different letters are significantly different $(p<0.05)$ from each other.

to that measured in 135-d-old fetuses after $29 \mathrm{~d}$ of continuous lung liquid drainage (135-d control, $2760 \pm 493 \mathrm{mg}$ versus drain, $2716 \pm 345 \mathrm{mg}$ ).

Weights and DNA and protein contents of other fetal tissues. In fetuses exposed to lung liquid drainage followed by reconnection of the tracheal circuit (drain and reconnect), the protein content of the heart tended to be higher than that measured in age-matched control fetuses (Table 2). Reconnection of the tracheal circuit also increased the protein content of the costal diaphragm above control values. None of the other treatments (drain, drain and reconnect and drain and obstruct) significantly affected the weights or DNA and protein contents of any of the other fetal tissues investigated.

\section{DISCUSSION}

Lung liquid drainage for $29 \mathrm{~d}$ greatly reduced lung growth causing profound pulmonary hypoplasia which would be con-
Table 2. Tissue weights and DNA and protein contents in control fetuses (135-d control) and fetuses exposed to continuous lung liquid drainage (drain), lung liquid drainage followed by reconnection of the tracheal circuit (drain and reconnect), and lung liquid drainage followed by tracheal obstruction (drain and obstruct)

\begin{tabular}{lcccc}
\hline \multicolumn{1}{c}{ Tissue } & 135-day control & Drain & $\begin{array}{c}\text { Drain and } \\
\text { reconnect }\end{array}$ & $\begin{array}{c}\text { Drain and } \\
\text { obstruct }\end{array}$ \\
\hline Wet weight $(\mathrm{g} / \mathrm{kg})$ & & & & \\
$\quad$ Heart & $7.9 \pm 0.5$ & $6.7 \pm 0.6$ & $8.8 \pm 1.5$ & $6.3 \pm 0.3$ \\
Liver & $23.0 \pm 1.5$ & $23.6 \pm 0.9$ & $21.6 \pm 1.1$ & $22.4 \pm 0.8$ \\
Kidney & $4.4 \pm 1.3$ & $6.1 \pm 0.4$ & $5.8 \pm 0.7$ & $6.2 \pm 1.2$ \\
Costal diaphragm & $2.1 \pm 0.1$ & $2.9 \pm 0.2$ & $2.2 \pm 0.3$ & $2.2 \pm 0.1$ \\
Vertebral diaphragm & $1.0 \pm 0.1$ & $1.2 \pm 0.2$ & $1.0 \pm 0.1$ & $0.8 \pm 0.1$ \\
Total DNA content & & & & \\
$\quad$ (mg/kg) & $30 \pm 2$ & $30 \pm 6$ & $31 \pm 2$ & $19 \pm 3$ \\
Heart & $130 \pm 35$ & $119 \pm 6$ & $121 \pm 10$ & $109 \pm 21$ \\
Liver & $26 \pm 7$ & $43 \pm 6$ & $31 \pm 3$ & $26 \pm 5$ \\
Kidney & $5 \pm 0$ & $7 \pm 1$ & $6 \pm 1$ & $5 \pm 1$ \\
Costal diaphragm & $3 \pm 0$ & $3 \pm 1$ & $3 \pm 0$ & $2 \pm 0$ \\
Vertebral diaphragm & & & & \\
Total protein content & & & & \\
$\quad$ (mg/kg) & $49 \pm 11$ & $39 \pm 5$ & $100 \pm 24$ & $37 \pm 10$ \\
Heart & $230 \pm 33$ & $212 \pm 23$ & $227 \pm 64$ & $105 \pm 5$ \\
Liver & $24 \pm 3$ & $20 \pm 1$ & $84 \pm 36$ & $26 \pm 12$ \\
Kidney & $9 \pm 1$ & $13 \pm 2$ & $18 \pm 1^{*}$ & $11 \pm 2$ \\
Costal diaphragm & $6 \pm 2$ & $5 \pm 1$ & $15 \pm 7$ & $7 \pm 2$ \\
Vertebral diaphragm & $6 \pm 2$ \\
\hline Asterisk indicates value significantly different from control $(p<0.05)$.
\end{tabular}

sidered incompatible with life in the human newborn (12). In this study, we have demonstrated that tracheal obstruction can rapidly (within $6 \mathrm{~d}$ ) reverse an existing lung growth deficit in utero. The effectiveness of tracheal obstruction in increasing lung growth and reestablishing a normal lung size (in terms of lung weight and DNA and protein contents) appears to depend upon the restoration of normal volumes of lung liquid within the future airways. This is supported by the finding that, after prolonged lung liquid drainage, reconnection of the tracheal circuit failed to increase lung liquid volumes to control levels and to increase growth of the hypoplastic fetal lung. Although reconnection of the tracheal circuit did increase the volume of fetal lung liquid, this increase and the associated reexpansion of the lung must not have been sufficient to stimulate lung growth.

Our finding that the absolute weights and DNA and protein contents of the lungs from 135-d-old fetuses exposed to $29 \mathrm{~d}$ of lung liquid drainage were either similar or less than values in 105-d-old control fetuses (i.e. age at which treatment commenced) indicates that lung growth virtually ceases as a result of liquid drainage. Indeed, the finding that the total lung DNA content was greater in 105-d-old control fetuses than in fetuses subjected to continuous lung liquid drainage suggests that either apoptosis had occurred or that a normal rate of cell death had occurred in the absence of a significant level of cell division. Whatever the explanation, these data provide further evidence to support the concept that lung growth in the fetus is particularly sensitive to changes in lung expansion. Furthermore, because growth of the lung was stopped by lung liquid drainage, it can be assumed that the lung DNA and protein contents at $135 \mathrm{~d}$ of gestation in drain fetuses was the same as 
at $128 \mathrm{~d}$ in drain and reconnect and drain and obstruct fetuses when the trachea was either reconnected or obstructed, respectively.

In fetuses with lung hypoplasia induced by prolonged lung liquid drainage, obstruction of the fetal trachea for only $6 \mathrm{~d}$ increased lung weights and total DNA and protein contents to near control values. In a previous study (4), we calculated that obstructing the trachea in fetuses with normal lungs increased the rate of pulmonary DNA synthesis to a level that was 48 $\mathrm{mg} / \mathrm{d}$ greater than that in control fetuses $(\sim 4 \mathrm{mg} / \mathrm{d})$, giving a total pulmonary DNA synthesis rate of $\sim 52 \mathrm{mg} / \mathrm{d}$. In this study, assuming that no DNA synthesis occurred between 128 and $135 \mathrm{~d}$ of gestation in fetuses exposed to continuous lung liquid drainage, we calculate that after obstruction of the fetal trachea the pulmonary DNA synthesis rate was $55 \mathrm{mg} / \mathrm{d}$. Thus, obstructing the trachea and thereby increasing the level of fetal lung expansion appears to be equally potent at stimulating increased pulmonary DNA synthesis in a hypoplastic lung as it is in a normally grown lung. However, the mechanism by which increased fetal lung expansion stimulates cellular proliferation within lung tissue is not known, although increased gene expression of different tissue growth factors is probably involved (4). We have previously shown that increases and decreases in fetal lung expansion correspondingly affect the relative abundance of mRNA encoding for IGF-II in lung tissue (4). Similarly, a reduction in fetal lung expansion induced by the abolition of fetal breathing movements $(13,14)$ also leads to a reduction in IGF-II mRNA levels (13).

When lung liquid drainage was stopped after $23 \mathrm{~d}$ and the tracheal circuit was reconnected for $6 \mathrm{~d}$, the pulmonary DNA and protein contents were not different from values in fetuses after continuous lung liquid drainage. This finding most probably resulted from the failure of lung liquid to accumulate in the future airways and to expand the lungs sufficiently to stimulate lung growth. In drain and reconnect fetuses, although the volume of lung liquid had increased by $2 \mathrm{~d}$ after the tracheal circuit was reconnected, no further increase occurred after $6 \mathrm{~d}$ despite the finding that lung liquid secretion rates were similar to control values. Under these circumstances (i.e. after $2 \mathrm{~d}$ ), liquid must have left the lung via the trachea at the same rate as it was produced and, therefore, had not accumulated within the future airways. In contrast, after tracheal obstruction lung liquid volumes progressively increased to control values after $6 \mathrm{~d}$, and associated with this increase in volume was an increase in tracheal pressure; the values measured were similar to the values we recorded in fetuses exposed to $7 \mathrm{~d}$ of tracheal occlusion (4). Consequently, we suggest that the generation of an intraluminal pressure that will expand the hypoplastic fetal lung to a level that will significantly stimulate lung growth, must be dependent upon the presence of a resistance to lung liquid efflux that is greater than that which normally occurs during fetal apnea as a result of glottic narrowing $(15,16)$. Indeed, the mean tracheal pressure measured in one fetus after reconnection of the tracheal circuit (drain and reconnect, $3.4 \pm$ $0.4 \mathrm{~mm} \mathrm{Hg}$ ) was similar to that measured in control fetuses at the same age.

During the period of lung liquid drainage (105-135 d) the rate of drainage, which must equal the rate of production, remained constant when expressed in milliliters $/ \mathrm{kg}$ of fetal body weight. This is in contrast to the normal increase in lung liquid secretion rates that have previously been observed with increasing gestational age $(17,18)$. Presumably lung liquid production rates did not increase relative to fetal body weight, due to the virtual cessation of lung growth as a result of lung liquid drainage. However, when lung liquid secretion rates at $134 \mathrm{~d}$ of gestation were expressed relative to the wet weight of the lung, they were much greater in lung liquid drained fetuses than in age-matched controls. This apparent stimulatory effect of drainage on fetal lung liquid secretion can probably be explained by the changes in hydrostatic pressure within the lung lumen caused by this manipulation (14). The osmotic pressure gradient driving fetal lung liquid secretion $(19,20)$ is normally thought to be opposed by the hydrostatic pressure $(\sim 1-2 \mathrm{~mm} \mathrm{Hg})(21)$ within the lung lumen $(1,14)$. It is logical, therefore, that the removal or reversal of this intraluminal hydrostatic pressure will increase the net production rate of fetal lung liquid. This phenomenon also probably explains the finding that tracheal obstruction almost totally abolished fetal lung liquid secretion throughout the period of occlusion. That is, after tracheal obstruction, net lung liquid production gradually decreases as the intraluminal pressure increases and eventually stops when the pressure required to further expand the lungs exceeds the osmotic pressure driving liquid secretion $(1,4)$. It would appear from this study, and our previous study (4), that the intraluminal pressure required to stop both net lung liquid production and further lung expansion is $4-5 \mathrm{~mm} \mathrm{Hg}$. We do not suggest that the hydrostatic pressure changes are affecting the ion transport mechanism that has been postulated to drive lung liquid secretion (19). Rather, we suggest that the hydrostatic pressure affects net liquid movement by altering the balance of forces regulating fluid movement across the epithelium. Although the intraluminal distending pressures are a very potent stimulus for fetal lung growth (4), they are relatively small and are unlikely to cause damage to the developing airways.

We considered that stopping the lung liquid drainage and reconnecting the tracheal loop after an initial period of lung liquid drainage was analogous to correction of an abnormality causing lung hypoplasia (e.g. surgical repair of a diaphragmatic hernia). That is, the original condition causing the hypoplasia was eliminated, but no attempt was made to expand the lungs. In view of our results, we suggest that correction of a condition causing lung hypoplasia, in the absence of tracheal obstruction, is unlikely to provide a sufficient stimulus to reverse the lung growth deficit in the short term ( $6 \mathrm{~d})$ because the lung will not expand sufficiently to stimulate lung growth. It is not surprising, therefore, that pulmonary hypoplasia persisted at birth after simulated surgical repair of a diaphragmatic hernia (22). Furthermore, we suggest that the failure of the hypoplastic lung to expand, in the absence of tracheal obstruction, is most probably the consequence of a relatively incompliant lung and, perhaps more importantly, chest wall (23). Under these conditions, the normal resistance to lung liquid efflux offered by the upper airway $(15,16)$ is probably insufficient to promote fluid accumulation and, therefore, increase lung expansion to the level required to stimulate lung growth. In contrast, obstruction 
of the trachea in fetuses with hypoplastic lungs quickly increases the degree of lung expansion to normal levels, accelerates lung growth and reverses the lung growth deficit in as little as $6 \mathrm{~d}$. Our findings support the recent observations that occlusion of the trachea increases lung growth in fetal sheep with hypoplastic lungs induced by either herniation of the fetal diaphragm (24) or nephrectomy (5). In the experimentally induced diaphragmatic hernia study (24), it was also shown that the increased lung expansion, caused by tracheal occlusion, successfully displaced abdominal contents from the tho$\operatorname{rax}(24)$, which supports our previous prediction (4).

Of the other fetal tissues investigated, only the diaphragm and heart were affected by the various treatments. Drainage of lung liquid for $23 \mathrm{~d}$ followed by reestablishment of tracheal flow for $6 \mathrm{~d}$ caused a significant increase in the protein content of the heart, but did not alter the heart weight-to-body weight ratio or the DNA content of the heart. This is an interesting observation but we are uncertain of its significance. Because the hypertrophy was not observed in either the drain or drain and obstruct groups, it is unlikely to result from an increase in pulmonary vascular resistance associated with the pulmonary hypoplasia.

In summary, this study has demonstrated that a short-term obstruction of the fetal trachea $(6 \mathrm{~d})$ can reverse a lung growth deficit in utero. On the other hand, reconnection of the tracheal circuit, which is analogous to correcting the condition causing the lung hypoplasia, does not provide a sufficiently large distending stimulus to accelerate lung growth. Further studies are required to determine whether lungs subjected to accelerated growth are functionally normal after birth.

Acknowledgments. The authors gratefully acknowledge the assistance of A. Satragno in the surgical preparation of these animals and the expert technical assistance of L. Stratford.

\section{REFERENCES}

1. Carmel JA, Friedman F, Adams FH 1965 Fetal tracheal ligation and lung development. Am J Dis Child 109:452-456

2. Alcorn D, Adamson TM, Lambert TF, Maloney JE, Ritchie BC, Robinson PM 1977 Morphological effects of chronic tracheal ligation and drainage in the fetal lamb lung. J Anat 123:649-660
3. Moessinger AC, Harding R, Adamson TM, Singh M, Kiu GT 1990 Role of lung fluid volume in growth and maturation of the fetal sheep lung. J Clin Invest 86:1270-1277

4. Hooper SB, Han VKM, Harding R 1993 Changes in lung expansion alter pulmonary DNA synthesis and IGF-II gene expression in fetal sheep. Am J Physiol 265:L403L409

5. Wilson JM, DiFiore JW, Peters CA 1993 Experimental fetal tracheal ligation prevents the pulmonary hypoplasia associated with fetal nephrectomy: possible application for congenital diaphragmatic hernia. J Pediatr Surg 28:1433-1440

6. Moessinger AC, Santiago A, Paneth NS, Rey HR, Blanc WA, Driscoll Jr JM 1989 Time trends in necropsy prevalence and birth prevalence of lung hypoplasia. Paediatr Perinat Epidemiol 3:421-431

7. Knox WF, Barson AJ 1986 Pulmonary hypoplasia in a regional perinatal unit. Early Hum Dev 14:33-42

8. Harrison MR, Langer JC, Adzick NS, Golbus MS, Filly RA, Anderson RL, Rosen MA, Callen PW, Goldstein RB, de Lorimier AA 1990 Correction of congenital diaphragmatic hernia in utero, V. initial clinical experience. J Pediatr Surg 25:47-57

9. Longaker MT, Laberge JM, Dansereau J, Langer JC, Crombleholme TM, Callen PW, Globus MS, Harrison MR 1989 Primary fetal hydrothorax: natural history and management. J Pediatr Surg 24:573-576

10. Hooper SB, Dickson KA, Harding R 1988 Lung liquid secretion, flow and volume in response to moderate asphyxia in fetal sheep. J Dev Physiol 10:473-485

11. Lumbers ER, Smith FG, Stevens AD 1985 Measurement of net transplacental transfer of fluid to the fetal sheep. J Physiol 364:289-299

12. Askenazi SS, Perlman M 1979 Pulmonary hypoplasia: lung weight and radial alveolar count as criteria of diagnosis. Arch Dis Child 54:614-618

13. Harding R, Hooper SB, Han VKM 1993 Abolition of fetal breathing movements by spinal cord transection leads to reductions in fetal lung liquid volume, lung growth and IGF-II gene expression. Pediatr Res 34:148-153

14. Miller AA, Hooper SB, Harding R 1993 Role of fetal breathing movements in control of fetal lung distension. J Appl Physiol 75:2711-2717

15. Harding R, Bocking AD, Sigger JN 1986 Upper airway resistances in fetal sheep: the influence of breathing activity. J Appl Physiol 60:160-165

16. Harding R, Bocking AD, Sigger JN 1986 Influence of upper respiratory tract on liquid flow to and from fetal lungs. J Appl Physiol 61:68-74

17. Olver RE, Schneeberger EE, Walters DV 1981 Epithelial solute permeability, ion transport and tight junction morphology in the developing lung of the fetal lamb. J Physiol 315:395-412

18. Hooper SB, Harding R 1995 Fetal lung liquid: a major determinant of the growth and functional development of the fetal lung. Clin Exp Pharmacol Physiol 22:235-247

19. Olver RE, Ramsden CA, Strang LB, Walters DV 1986 The role of amilorideblockable sodium transport in adrenaline-induced lung liquid reabsorption in the fetal lamb. J Physiol 376:321-340

20. Olver RE, Strang LB 1974 Ion fluxes across the pulmonary epithelium and the secretion of lung liquid in the foetal lamb. J Physiol 241:327-357

21. Vilos GA, Liggins GC 1982 Intrathoracic pressures in fetal sheep. J Dev Physiol 4:247-256

22. Harrison MR, Bressack MA, Churg AM, de Lorimier AA 1980 Correction of congenital diaphragmatic hernia in utero. II. Simulated correction permits fetal lung growth with survival at birth. Surgery 88:260-268

23. Jakubowski AE, Billings K, Johns DP, Hooper SB, Harding R 1993 Respiratory function in lambs following prolonged oligohydramnios during late gestation. Pediatr Res 34:611-617

24. Hedrick MH, Estes JM, Sullivan KM, Bealer JF, Kitterman JA, Flake AW, Adzick NS, Harrison MR 1994 Plug the lung until it grows (PLUG): a new method to treat congenital diaphragmatic hernia in utero. J Pediatr Surg 29:612-617 